\title{
AFGHAN CARAVAN TRADE AND IMPERIALISM IN INDIA ${ }^{1}$
}

\author{
COMERCIO DE CARAVANAS AFGANAS E IMPERIALISMO EN INDIA
}

\author{
André Wink ${ }^{2}$
}

\begin{abstract}
It is often supposed that Afghanistan has historically been the 'graveyard of empires'. 'It is today's textbook example of a 'failed state.' Afghans, however, should be considered among the most important empire builders of Asia in the 15th and 16th centuries. In this paper it is shown that in South Asia, the physical infrastructure of caravanserais and roads created by Afghan nomadic caravan traders known as powindas was fundamental to the development of the empires of the Indo-Afghans (1451-1556), as well as to the Mughal empire (1526-1857), and ultimately the British Raj of the 19th and 20th centuries.
\end{abstract}

Key words: Afghanistan, India, caravan, Mughal Empire, powinda.

A menudo se supone que Afganistán ha sido históricamente un "cementerio de imperios" y se presenta en los manuales como ejemplo de "sistemas estatales fracasados". Los afganos, sin embargo, deberían ser considerados los más importantes constructores de imperios de Asia del sur en los siglos XV y XVI. En este estudio se muestra que en el sur de Asia, la infraestructura física de caravaneros y caminos creados por las caravanas nómadas de mercaderes afganos conocidos como powindas fue fundamental para el desarrollo de los imperios Indo-Afganos (1451-1556), así como para el imperio de Mughal (1526-1857), y finalmente el Raj británico de los siglos XIX y XX.

Palabras claves: Afganistán, India, caravanas, imperio Mughal, powinda.

In the medieval (7th-15th) centuries, Afghanistan was a (semi-) arid and in many places cold country, a wild assemblage of hills, mountains covered with perennial snow, and wastes unmarked by enclosures even in the cultivated parts, destitute of roads or navigable rivers and canals, with only a few towns at great distance from each other, and, above all, overwhelmingly poor (Figure 1, Table 1). Astride of what the Bâburnâma (1993 f. 141b) describes as some of the 'most worthless mountain zones in the world,' this country had been a genuine pastoral-nomadic habitat since ancient times. It was the eastern part of what constitutes Afghanistan today, together with a sizable but narrow strip of Pakistan. As it was still known to Babur, medieval Afghanistan was an area to the south of Kabul on both sides of the Sulayman mountain range, extending down to the Indus river, and generally mentioned together with Bangash, Bannu and Dasht. This was the southern part of what modern scholarship has referred to as 'IndoKhurasan' and, with less precision, the 'Indo-Iranian frontier,' i.e. the middle part of the Makran-Pamir shatter zone running from the Makran coast on the Arabian Sea to the Pamir Knot and the Karakorum Range in Central Asia. Located in the southern part of the country of Roh, this (semi-) arid and mountainous region to the west of the Indus and south of the Hindu Kush, containing only a modest amount of land for agriculture, was and still is eminently suitable for pasturing large flocks of sheep and goats. With that of Baluchistan and parts of Sind, the western Panjab, and Rajasthan, Afghanistan's pastoral and mixed pastoralagricultural economy was the closest approximation to be found in South Asia to the purely nomadic economies of the arid zone of Persia and the much vaster open spaces beyond the Hindu Kush mountains which historically were known as Turan, the steppe lands of the Turko-Mongol world.

\section{The Pastoral-Nomadic Economy of Afghanistan and Kabul}

The ethnogenesis of the Afghans (also known as Pashtuns, and in India as Pathans or Rohillas)

\footnotetext{
${ }^{1}$ An earlier version of this article was presented at the International Workshop "Caravan Archaeologies: En Route to the Past, Present and Future", Pica, Chile (May 2017). This manuscript was evaluated by external reviewers and edited by the Chungara Editorial Committee and the invited editors Persis B. Clarkson and Calogero M. Santoro.

${ }^{2}$ Institute for Research in the Humanities, University of Wisconsin, Madison, USA. awink@ wisc.edu
} 


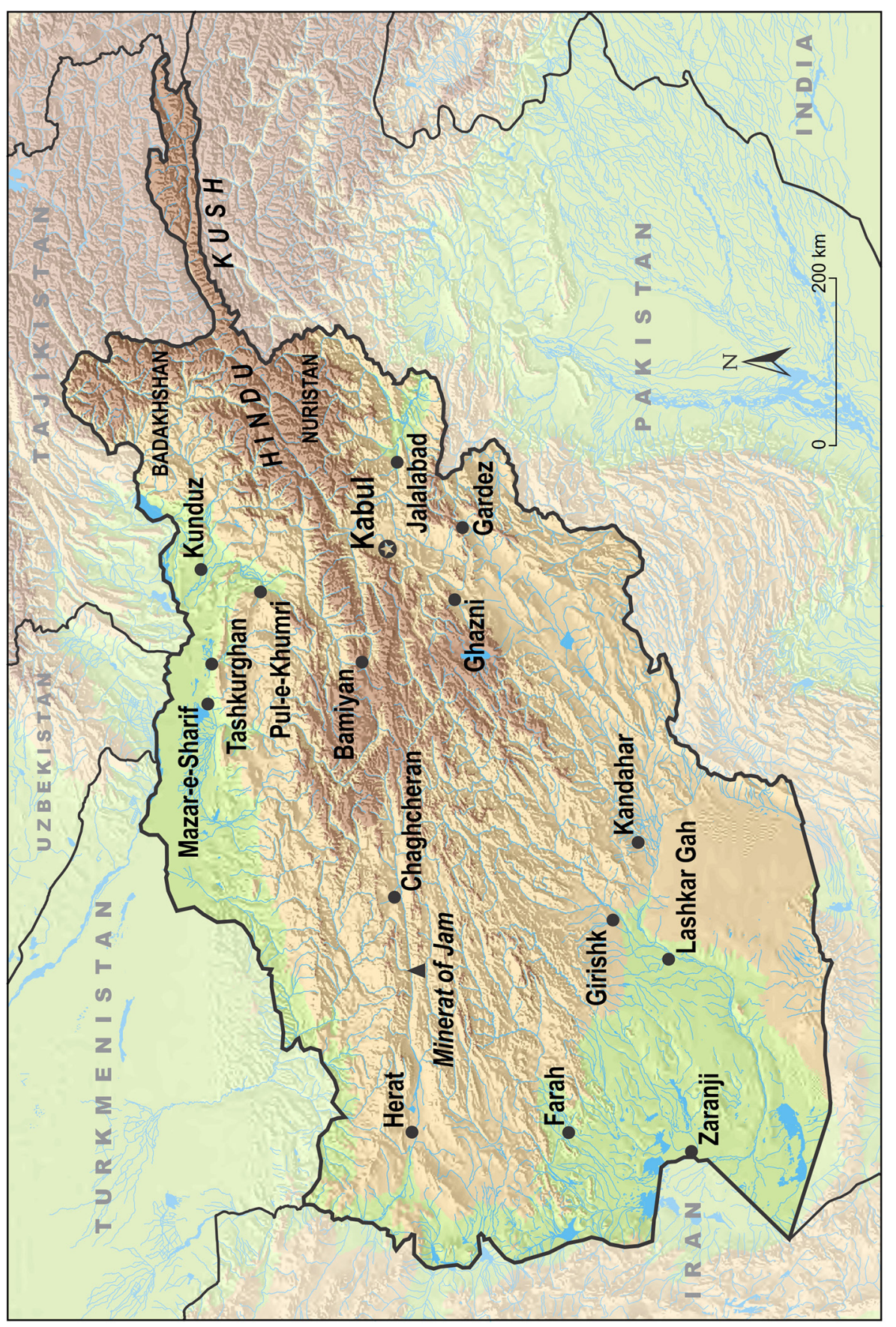

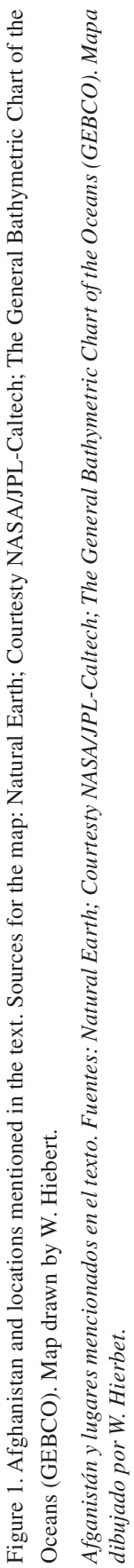


Table 1. Chronological sequence of political regimes and key historical events in medieval Afghanistan.

Secuencia cronológica de los regímenes políticos y los acontecimientos históricos claves en el Afganistán medieval.

\begin{tabular}{ll}
\hline \multicolumn{1}{c}{ Regime } & \multicolumn{1}{c}{ Date } \\
\hline Delhi Sultanate & $1206-1526$ \\
Lodi Sultanate & $1451-1529$ (the last dynasty of the Delhi Sultanate) \\
Timur destroys Delhi & 1398 \\
Mughal Empire & $1526-1857$ \\
Sur Afghan Empire & $1540-1556$ (also known as the Afghan interregnum) \\
\hline
\end{tabular}

in this area is an obscure and entangled process that took place over centuries and involved successive waves of nomadic migrations into and through the Afghan 'homeland.' The medieval Afghans shared in a common nomadic culture -called küchi or powindasupplemented with rudimentary agriculture, hunting and gathering, highway robbery, and with longdistance trade between India and Khurasan along the routes of their annual migrations (Arlinghaus 1983; Bâburnâma 1993; Elphinstone 1992; Wink 19902004). The summer pastures or yaylaqs of the Afghan nomads were in the upland portions of southern Indo-Khurasan: the Sulayman mountain range and the Ghazna plateau. On some of the relatively wellwatered and fertile soil near their summer pastures they planted wheat and barley. After the autumn harvest they brought their flocks of sheep and goats down from the mountains and the plateau to the winter pastures or qishlaqs at lower altitudes in the other subregions of Indo-Khurasan. Among the various trajectories of Afghan nomadic migration, the most important were those to the Derajat in the Indus river valley, the Kabul river valley, and Qandahar. The Derajat was a natural winter grazing area for Afghan nomads. Especially below Kalabagh, the snow-fed Indus river inundated a wide area and when the river retreated in the fall and winter it left the flood plains moist and rich with grasses. Many of the Afghan nomads following the routes from the Ghazna plateau to the Indus river flood plains engaged in trade or hired themselves out as camel drivers. Those who migrated between the Ghazna plateau and northern IndoKhurasan had their winter pastures at lower altitudes along the Kabul river, in such tumans or 'districts' as Nangrahar or Lamghanat - here the Afghan nomads, by Babur's time, had taken control of the trade along the Khyber route, between the Panjab and Khurasan and Turan. The third trajectory of Afghan nomadic migration, between the Ghazna plateau and the relatively low and snow-free valleys around Qandahar (of the Arghandab, Tarnak and Arghastan rivers) is known to have been followed regularly throughout the medieval centuries, and in Babur's time was especially favored by the Ghilzais, who tended extremely large flocks of sheep, but as a rule did not engage in trade.

The pastoral nomads of medieval Afghanistan, then, kept large herds of sheep and goats, as well as some camels and horses (on which more below), where grazing land was sufficient, supplementing pastoralism with agriculture where possible, and engaging in trade mostly where their nomadic migration patterns coincided with trade routes. This was a fundamentally pastoral-nomadic society in which kinship was the main organizing principle of tribes -not territory- and in which there was no place for chiefs or kings. Medieval Afghanistan was, in other words, not a kingdom.

If there was one fundamental difference between the pastoral-nomadic economies of medieval Afghanistan and Turko-Mongol Central Asia, it was that the first had a very limited potential for horsebreeding. In Afghanistan, as Elphinstone put it, 'the great stock of the pastoral tribes is sheep, and those of the kind called in Persian Doomba, and remarkable for tails a foot broad, and almost entirely composed of fat' (Elphinstone 1992: I, p. 190). Goats were also common in all the mountainous parts of the country, and by no means scarce in the plains. Afghan nomads who lived near the deserts had camels, while the poor used bullocks and asses, and almost every man had a horse; but in general the horses of the Afghan dominion -even in its much extended eighteenth- and nineteenth-century version- were "not remarkably good' (Elphinstone 1992: I, p. 189). It is, hence, somewhat paradoxical that in the course of the medieval centuries Afghan traders acquired a near monopoly of the trade in horses between Central Asia and India, and that this trade became one of the driving forces of Afghan migration and political expansion into India. According to Babur, every year seven, eight or ten thousand horses were brought to Kabul by Afghan traders (saudägarän), and these included both 'thoroughbred horses' (aspān-i-tapchaq) and 'trade horses' (aspān-i-saudā) (Bâburnâma 1993: ff. 129, 148b). Great numbers of excellent horses were sold annually by Afghan traders in India under the name of 
'Kabul' and 'Qandahar' horses, but these were almost all from Balkh, a province of Turkistan, or from Bukhara and the Turkman country. Afghan traders bought these horses cheap, when they were thin and in bad shape, and would then fatten them up in and around Qunduz, or near Parwan and Charikar, or in the Wilayat of Kabul - the latter, although it lay in the midst of mountains, had some good pastures where 'the grass agrees with horses, and there are few flies [in spring and summer]' (Bâburnâma 1993: ff. 130, 141b). Overall, the summer pastures of Afghanistan and Kabul 'could scarcely be compared to those of Farghana and Mughalistan' (Bâburnâma 1993: f. 140b)

Afghan nomads, as all the evidence shows, raised huge numbers of sheep, and not many horses, whereas the Turko-Mongol nomads of the steppes raised both huge numbers of sheep and excellent horses. The Afghans, to be sure, were not the only pastoral nomads in the areas that now comprise modern Afghanistan. Competing with them for space, there were numerically important fragments of medieval Turko-Mongol nomad tribes. These went by a variety of names, and the ethnic boundaries between them -and between them and the Afghans- are far from always clear and, moreover, appear to have been in constant flux. Turko-Mongol nomads in origin, none of these groups entirely abandoned pastoralism in this environment; nor did they entirely lose their mobility and warlike character. But many of them sedentarized and took up agriculture; and in so far as they preserved pastoral nomadism, they -like the Afghans- specialized largely in sheep-raising, and either abandoned horse-breeding altogether or limited themselves to the production of small, hardy breeds of ponies suitable for transportation purposes and carriage but not for warfare.

\section{Afghan tribal society}

Up to the fifteenth and early sixteenth centuries, the economy of the Afghans and other pastoralnomadic populations of the Kabul Wilayat and its Kohistan extensions was thus primarily based on sheep raising, while horse breeding was limited, and agriculture and trade were supplementary activities for the pastoral-nomadic populations themselves and practiced full time only by sedentary, Persianspeaking Tajiks and other peasant populations settled in villages scattered or clustered throughout much of the area. The Afghans typically lived in black tents and shared a common küchi or powinda, that is to say nomadic, culture that set them apart from peasants and townspeople alike and remained an essential part of Afghan tribal life until recent times. Afghans who lived in villages continued to share in this culture, engaging in agriculture in a distinct and less laborious fashion. Such Afghans still lived in tents or mat huts during the part of the year they spent in their qishlaqs or winter pastures, while Tajiks did not spend any part of the year in tents or mat huts.

Being pastoral and nomadic, the basic organizing principle of Afghan society was not territory but kinship. Tribal ideology valued kinship solidarity and respect for lineage elders above all else, while also promoting individual freedom, generosity, bravery, a strict sense of honour, and the aspiration of fiscal independence. Each tribe or ülüs constituted 'a complete commonwealth within itself' (Elphinstone 1992: I, p. 210) and consisted of segmentary lineages, also called $\bar{u} \bar{u} \bar{u}$, which were theoretically all descended from a single ancestor. Unlike Tajiks who identified with a town, village or region, Afghans defined themselves in kinship terms and knew the genealogies of their patrilineal descent groups over six or seven generations. This was the reason Afghan tribal society knew of no chiefs or rulers and was fundamentally egalitarian, a kinship of equals. Leadership was in the hands of maliks or khans -the natural elders or heads of lineages and tribes- but effective power and authority rested with tribal councils or jirgas. A famous saint among the Yusufzai Afghans is said to have left his tribe this blessing and curse, 'That they should always be free, but that they should never be united' (Elphinstone 1992: I, p. 231). Throughout history, the Afghan tribes failed to develop kingdoms or chiefdoms in Afghanistan itself, with the exception only of the Ghilzais and the Durranis or 'Abdalis' in the eighteenth century. Even in the eighteenth century, Ahmad Shah Abdali required less exertion to conquer all neighbouring kingdoms than to subdue his own countrymen.

The tribal customary law of Pashtunwali embraced the notion that it was every man's right and duty to do himself justice, and also included hospitality (melmastia), revenge (badal), and giving refuge (nanawatai). Any violation of this code would result in a deeply dreaded loss of honour, and the invocation of shame or peghor, insult or humiliation. Pashtunwali, as a tribal code, was fundamentally at odds with Islamic religious law, and purda, the concealment of women, was traditionally not part of it and only developed at a later stage when the Afghan nomads moved from open-air camping grounds into the seclusion of towns. Hospitality did not extend beyond the lands of the tribe, and particularly the most pastoral tribes were prone to robbery -although not normally murder, or wanton cruelty- of strangers and trespassers with whom they had no genealogical relationship. Especially the Afridi, Shinwari and other 
Afghans of the Khyber pass were notorious for the rapacity with which they attacked caravans coming through their lands; and so were all tribes of the Sulayman mountains.

Even within the tribes there was constant discord about zan, zer and zamin (women, wealth and land). The slightest occasion would give rise to a dispute; extreme jealousy prevailed. The tribesmen lived in constant fear of violence and never went about unarmed. This characteristic feature of Afghan life was what outside observers like Elphinstone referred to as the 'turbulence of the tribesmen' or 'a state of anarchy,' (Elphinstone 1992: II, pp. 21, 23) the same phenomenon that the mass media of today refer to as the 'lawlessness' of the frontier. Masson says that 'the Khaibaris, like other rude Afghan tribes, have their maleks, or chiefs, but the authority of these is very limited; and as every individual has a voice on public affairs, it is impossible to describe the confusion that exists amongst them' (Masson 1997-2001: I, p. 163). It was the same 'clannish spirit' that made Afghan unity difficult or impossible to achieve, even though it did not preclude an interest in the honour of the Afghan name - as the verses of the Pashto poet Khushal Khan Kattak (1613-1689) make clear. In practice, lineages cooperated at the lowest level necessary to meet an outside challenge; tribal alliances were ad hoc, and tribal confederations were the exception in Afghan history and disintegrated at the first opportunity. Afghan nomads rarely paid taxes in kind or in services, let alone cash, even after they sedentarized.

The Afghans' attempts at empire building thus stand in sharp contrast to those of the Turko-Mongols in that they were always thwarted sooner or later by their inability to overcome their tribal ways. The historical record shows how at first the Afghans were auxiliaries in the Turkish-led jihad campaigns in India. As such their role was by no means insignificant, even though Afghan historians of the seventeenth and eighteenth centuries are prone to exaggerate it, particularly in the earliest stages of Islamic expansion under the Ghaznavids, and often proclaim the Afghans to have been a crucial element in these campaigns. From the thirteenth century onwards the Afghans were at times enlisted as auxiliaries by the Mongols, and they were often deployed in frontier warfare by the Delhi Sultanate (Table 1), or as infantry in especially treacherous mountain terrain, or as garrisons of hilltop fortresses. Afghan conversion to Islam definitely accelerated in this context of imperial expansion. By the thirteenth century the area of Afghan nomadic activity was also expanding beyond the Sulayman mountains, and we begin to see Afghan nomads occupying new lands in places like Binban and Ghur, while later in the same century they also began moving towards the Khyber pass and Peshawar, towards Qandahar, and into Mastung, northern Baluchistan. With the advent of the Mongols, large areas of the Panjab -including the Sind Sagar Doab, the Potwar plateau, and the Jech and Rechna Doabs up to the Ravi river- began to suffer significant population losses and here too nomadic Afghans, with numerous other ethnic groups, including Turks, began to move in (Raverty 1888:222). In the wake of Timur's withdrawal there was again a general movement of all kinds of nomadic tribes seeking new lands on both sides of the Indus.

Generations of Afghans thus achieved a modest measure of prominence within the context of the emerging Indo-Islamic states, and there is evidence of some intermarriage between Afghans and Turks, Mongols, Khalaj, as well as Indians. In India, the Afghans were often bracketed with the Khalaj (pastoral nomads of the plateaux of Kabul and Bust, most likely a residue of the early Shaka, Kushana and Hephthalite invaders), and in the late thirteenth and early fourteenth centuries it was especially the Khalaji dynasty (1290-1320) that promoted them. Afghans played a substantial but still auxiliary military role under the Tughluq dynasty of Delhi (1320-1414) as well as under some of the regional Indo-Islamic dynasties that emerged in the second half of the fourteenth century, in Gujarat, Malwa, Bengal, Jaunpur, Multan, as well as in the Panjab, parts of the Doab, and possibly elsewhere. Up to the mid-fifteenth century, however, there was no independent Afghan dynasty that made an attempt to build an empire of its own.

\section{The failure of empire}

The reason no such attempt was made is that up to the mid-fifteenth century there were no significant changes in Afghan society that had the potential to undermine its tribal structures. Ultimately, that kind of change could only be brought about by the increase of commercial traffic through Afghan territories. Here is where the roots of Afghan empire building can be found.

For centuries Afghans of various tribes had been migrating in the autumn from their mountains and plateaus to the valley of the Indus, spent the winter in what in 1901 was named the North-West Frontier Province (NWFP) and since 2010 is renamed KhyberPakhtunkhwa, the adjacent tribal agencies or FATA territories of Pakistan, the Panjab, and Baluchistan, and had been returning in the spring. Known throughout these regions as either $k \bar{u} c h \bar{s}$, powindas or mäldärs ('wealth-owners'), these Afghans enjoyed the great advantage over other pastoral nomads that their 
annual pastoral migrations coincided with important trade routes between India, Persia and Turan. Afghan pastoral nomads drove flocks of sheep and goats, rented out camels, guarded caravans, and engaged in caravan trade, particularly trade in imported horses - an ever more crucial commodity on the Indian markets. While all Afghans were alike in the sense that they shared the same tribal culture, spoke Pashto, and were at least nominally Sunni Muslims of the Hanafi school, subtle but in the long term significant differences existed or could arise between the purely pastoral nomads and the pastoral nomads who were also engaged in trade (Robinson 1978). The tribes whose country enabled them to raise camels were more likely to gain ascendancy in some of the trade and thus had an initial advantage over those who did not have that ability. The trading nomads would travel in caravans of camels, or of mules, donkeys, and bullocks, mostly carrying the goods of others and only sometimes their own, and they would travel greater distances than the purely pastoral tribes. While the purely pastoralist nomads would remain in the hilly tracts or along the skirt of the hills, the trading nomads would more commonly pitch their tents in the plains and sometimes leave their families in Afghanistan. With or without their families, the trading nomads reached into the furthest regions of the subcontinent (as far as Bihar, Bengal, the Deccan, and Gujarat), and in the other direction traveled to Qandahar and from there as far as Persia, and, with horses and ponies, across the Hindu Kush, to Bukhara. The caravans, often traveling at night, did not encamp in the country at the end of their journeys, like the pastoral tribes, but put up in caravanserais in towns - large square structures, surrounded by apartments, with a mosque and often a bath in the middle, and a common gateway.

By the fourteenth and fifteenth centuries, in the wake of the late-medieval upsurge of trade, Powinda pastoral-nomadic tribesmen had become the primary carriers of a huge volume of merchandise of all kinds (textiles, spices, horses, and many others), operating in caravans of ten, fifteen, or twenty thousand pack animals. They maintained a very extensive trading network. The roads traveled by the Powinda caravans, at about thirteen to sixteen kilometers (eight to ten miles) per twenty-four hour day, were among the most discouraging imaginable, leading northwards from Kabul through the Panjshir, Parwan and Ghurband valleys, on to the passes of the Hindu Kush, to Qunduz and Baglan, and eastwards through Nangrahar, the Khyber pass and then the Peshawar plain, crossing the Indus at Hazro, almost twenty-four kilometers (fifteen miles) above Atak, or at Nilab, sixteen kilometers (ten miles) below Atak; or they went through the Logar valley towards Ghazna or Gardiz, and through the Gomal, Tochi and Kurram river valleys, to the
Derajat and Bannu. In general the Powindas or trading nomads were even more democratic in their internal government than the purely pastoral tribes of the Afghans. The hereditary maliks of these Afghan trading nomads were often chiefs in name only, possessing nothing more than a shadow of influence, and even that only during the annual migration, or when fighting was imminent, and the trading nomads were far more impatient of being controlled by their own maliks or any government than other Afghan tribes. The trade as such did not bring any fundamental changes to the Afghans' tribal politics. But the horse trade, like nothing else, gave Afghan trading nomads access to the courts of the Indo-Muslim kings, providing extraordinary influence and privileges, and, as importantly, political intelligence as well as an initiation into a more sophisticated courtly life style that the purely pastoral tribes missed out on. The horse trade was also the one and uniquely important way for Afghans to accumulate wealth, and therefore one of the few sources of inequality in the pastoral and semipastoral tribal economy, since tolls and booty obtained in raids and warfare were always divided in equal shares among the tribesmen but not the profits made in the horse trade. When nomadic Afghan tribesmen engaged in the horse trade, discrepancies in wealth could become pronounced, and these did have the potential of breaking down the tribal social structure predicated on the kinship of equals.

It is therefore significant that the Lodi nomad tribes living along the trading routes of the Tochi and Gomal valleys were the first Afghans to combine nomadism and the horse trade in a major way. The immediate ancestors of Bahlul Lodi, the founder of the first Afghan empire of Delhi in the second half of the fifteenth century (Table 1), were associated with the caravan trade in horses and had frequented India for many years. In addition, under pressure from the growing power of the Ghilzais on the Ghazna plateau, some maliks of the Lodis had come out of Roh and, on the banks of the Indus, took the opportunity to join Timur, providing him with contingents of horsemounted warriors as well as supplies of horses for his expedition to Delhi in 1398 (Raverty 1888: Appendix, p. 22; Table 1). The Lodis' rise to political and military ascendancy continued during the first half of the fifteenth century, when numerous members of their tribe (together with other Afghans) were recruited by the Sayyid dynasty of Delhi (1414-1451). By the 1440s the Lodis were really the prop of the Sayyids' power. But it was with the support of his fellow Afghan tribesmen that Bahlul Lodi subjected the Panjab and was able to seize the throne of Delhi in 1451.

In that year the Lodis became the first Afghan royal dynasty in history, and as such held on to power until 1526 . The dynasty was able to assert its authority 
over much of northwestern and northern India, absorb the territories of the Jaunpur rulers to the east, and, to a degree, succeeded in transforming its initial tribal constituency into a more hierarchically structured and even 'imperial' monarchy. It did so gradually, after severing the tribesmen from their homeland.

Sultan Bahlul Lodi still recruited Lodi Afghan tribesmen from Roh by appealing primarily to their sense of honour and to kinship solidarity. Enlisting on an individual basis, many Lodis desired to return to Roh after each campaign season, even though the Sultan offered them every possible incentive to stay in the form of revenue assignments (iqta's) and governorships. In due course, however, a majority of the Lodi Afghans, together with members of smaller tribes such as the Sarwanis, Jalwanis and Kakars as well as neighbouring non-Afghan peoples such as the Farmulis and Barkis, migrated to India and became separated from the Afghan tribes west of the Indus. The first Lodi Sultan continued to assure his fellow tribesmen that he was a king in name only and that their joint conquests in India were going to be held by all Lodi tribesmen together, under a sharing arrangement. Loyalty to tribe or clan and kinship thus remained, for some time, the main organizing principle, and the revenue assignments and governorships enjoyed almost complete autonomy, while other Afghan tribes, such as the Niazis and Surs, were excluded from all important posts on a tribal basis. Before his death, Sultan Bahlul Lodi divided the Afghan dominion among his sons and relatives, with only Delhi and some districts in the Doab going to his heir and successor Sultan Sikandar Lodi (r. 1489-1517).

This Afghan tribal organization, however, came under increasing pressure from non-Afghan elements that entered the empire on different terms. Already Sultan Bahlul Lodi employed nearly 20.000 Mongols in his service, and he had begun to increasingly involve the Farmulis in his government. The latter were a Tajik ethnic group named after its district of origin, southeast of Ghazna, whom the Lodis had become associated with during their annual migrations through the Tochi and Gomal valleys. The Farmulis were useful to the Afghan king because they allowed him to have non-Afghan amirs who were loyal and subordinate to him personally rather than 'sharers' of his power. Sultan Sikandar Lodi, himself born of an Indian mother, expanded the policy of absorbing non-Afghan elements, and subsequently, after destroying the Sharqi Sultanate of Jaunpur in 1479, sponsored a large influx of Tajiks, Mongols, and especially Indian Rajputs into his realm. During Sikandar Lodi's reign, after repeated but half-hearted experiments with dual kingship, it became clear that in India tribal sharing arrangements were not going to work. Although not yet abandoning tribal politics altogether, Sikandar Lodi attempted to do away with the autonomy of the revenue assignments, promoted more and more Rajputs to high positions in his government, and introduced a more intrusive form of supervision throughout the provinces of his realm. Sikandar's son Ibrahim Lodi (r. 1517-26) abandoned tribal politics altogether and attempted to reduce all Afghans to servants of the state, introducing a ranking system of mansabs among his nobles, and in the end even keeping his own brothers out of any sharing arrangements - although not without briefly reviving dual kingship one final time. Their tribal sense of independence threatened, the Lodi Afghan nobility revolted and then solicited Babur to assist them in regaining their power. Babur, however, terminated the Lodi dynasty and dispersed its Afghan followers to Bihar and Bengal, and to Gujarat. At Panipat, as one chronicler explains, 'although the Afghan army (sipä' afghāni) greatly outnumbered its opponents, yet the soldiers were dispirited and disheartened due to the Sultan's ill-treatment [of them] and because the nobles were offended' (Hidayat Hosain 1939:22, 84).

\section{The Sur empire of the sixteenth century}

In sum, to the west of the Indus the Afghans were unable to overcome the limitations of their tribal institutions and create states or empires. In India, to the east of the Indus, Afghan empire building got under way but was aborted. The empire of the Lodis had ceased to exist by 1526 , leaving many Afghans adrift. 'These Afghans,' wrote Ahmad Yādgār, 'after being absolute rulers for seventy years, left their habitations, their goods, and their wealth behind, and proceeded to Bengal, and [there] they were completely dispersed'(Hidayat Hosain 1939:99).

One of them, a soldier named Dattu Sarwani, wrote an unique account of his dreams and reminiscences. His account is telling evidence that after the demise of the Lodi empire the Afghans left behind in Hind reverted to their tribal and migratory life style of old (Digby 1965). Dattu provides a vivid picture of the tribal hordes of Lodis, Luhanis, Surs, Niazis, as well as his own tribe of Sarwanis, moving incessantly across the plains with their women, children, and even some sheep, and how they did so in considerable numbers, setting up temporary tribal camping grounds (maydān-i-bāshish), and still speaking Pashto among themselves. The symbolism of the account is still entirely pastoral nomadic. Dattu describes a vision of the world spread out before him which was not one of a city but of a great encampment with many tents on a broad plain - an encampment from which one day one must pack up and go away. The portable darbar 
tent or barga was the visible symbol of sovereignty for this Afghan soldier, not the monumental mosques, tombs, fortresses, and caravanserais left behind by the Lodi emperors.

What Datta Sarwani did not know is that there would be a remarkable resurgence of Afghan power soon after his account was written. After defeating the Mughals in battle, a second and final attempt to transform the Afghan tribal structure into an empire was undertaken in Hindustan by the formidable Sher Shah Sur between 1540 and 1545 (Table 1). Determined to overcome the deficiencies of his Lodi predecessors, Sher Shah Sur introduced important changes in the constitution of the Afghan polity, followed by fiscal and revenue reforms, and he might have succeeded in his aim to keep the Mughals out of Hindustan if he had not died prematurely from a gunpowder explosion in his own arsenal. As it happened, the Sur empire did not survive Sher Shah very long and fell prey, like its Lodi predecessor, to the customary Afghan tribal disunion, thus creating the conditions for the Mughal re-conquest of 1555-6 under Babur's successors Humayun (r. 1530-1556) and Akbar (r. 1556-1605). Under his son Islam Shah (1545-1554) and the latter's bickering successors the second Afghan empire quickly unraveled.

The events of Sher Shah's reign are narrated by Abbas Khan Sarwani (1964), an Indo-Muslim historian of Afghan origin who wrote around 1580 AD. As a witness to Akbar's success, Abbas Khan Sarwani (1964), like no other historian of his time, was concerned with the historic failure of the Afghans. An almost Gibbonian sense of melancholy pervades the pages of his Tä'rkkh-i-Sher Shähi as it belabors the decline and fall of the Afghan empire (Sarwani 1964).

Sher Shah Sur's reign was exceptional in Afghan history, according to Sarwani, for several reasons. Firstly, because Sher Shah, born Farid and known merely as Sher Khan until 1539, was an exceptional personality. Secondly, Sher Shah's tribal genealogy made him a relatively marginal figure, and therefore less interested in a potential restoration of Lodi authority and more inclined to overhaul the very fundamentals of the tribal constitution. Sher Shah belonged to the minor Afghan tribe of the Sürs from his father's side and this made him an outsider among the leading Lodi Afghans of his time. His grandfather and father had been horse caravaneers when together they migrated to India from the Sulayman mountains during the reign of Bahlul Lodi, but 'had no distinction among the crowd of tradesmen'(Sarwani 1964: I, p. 8; II, p. 5) Thirdly, Sher Shah was born and raised in India, and, like most Indo-Afghans, was relatively unaware of 'Afghan custom' (rawish-i-afghāni) and the notions of tribe and clanship that informed the sense of honour of the inhabitants of Roh or, as Sarwani calls them, the 'Rohillas' (Sarwani 1964: I, pp. 232, 234; II, pp. 186-8). An assimilated Afghan, Sher Shah's genealogy from his mother's side is under dispute. Most Afghan historians hold that his mother was a Sarwani Afghan; but the bardic traditions of India surmise that his mother had been a daughter of the Qaimkhani Rajput family of Shekhawat and thus regard him as half-Indian.

Long before he became Sultan in 1539, probably as early as the second decade of the sixteenth century, Sher Shah began building a power base for himself in Sahsaram, in what are now the Rohtas and Bhojpur districts of southern Bihar. One of eight sons, Farid, the later Sher Shah, began his career by challenging the established Afghan custom ( $q a^{-}$ìda' rasm-i-afghänān) of inheritance sharing among brothers. Invoking a rule introduced by Sultan Sikandar Lodi that the normal laws of inheritance did not obtain in public affairs, he lost no time eliminating his brothers from the management of the two parganas of his father's jagir. From these early beginnings until 1529 Sher Khan was a successful commander who divided his time and energies between administering his father's parganas in southern Bihar and service with a variety of warlords in Awadh as well as with Sultan Ibrahim Lodi and the Mughal emperor Babur. Sher Khan was just one of many Afghans who entered Babur's service and thereby obtained an opportunity to study Mughal methods of warfare and military organization firsthand. He was the only Afghan, however, who already then conceived of the possibility of undermining Mughal rule in India and bringing it to an end. Among the Mughals, he observed, corruption and venality were rife, and greed, 'the lust for gold,' prevailed at all levels of the officialdom, so that friendship and enmity were decided more by money than anything else. If only he could unite the Afghans, the Mughals would not be able to withstand him.

Accordingly, it became Sher Khan's overriding goal and ambition in life to bring together the Afghans and undertake a joint effort to expel the Mughals from India and re-establish Afghan rule. In 1529 he resolutely left the Mughal camp and entered the service of the newly established Luhani Sultanate of southern Bihar. The Luhanis or Nuhanis were more numerous and stronger than the Surs at that time, trader nomads who had been in the possession of extensive jagirs for three generations under the Lodis, but the Luhani Sultanate was a tribal and short-lived affair. When the Luhani Sultan died in 1529, the entire management of southern Bihar devolved upon Sher Khan, giving him a measure of independence for the first time, but still essentially leaving him a servant of the Luhani clan and in modest circumstances. The following 
decade between 1529 and 1539 -which preceded his successful overthrow of Babur's successor Humayunis noteworthy for his dogged pursuit of independent wealth by a series of successful efforts, including multiple marriages with wealthy widows of the Luhani, Sarangkhani and Farmuli clans, to possess himself of the hoarded wealth and treasure of some of the most important remaining amirs of the defunct Lodi Sultanate, the acquisition of booty and spoils in many places, especially in Bengal, and even subsidies from Sultan Bahadur Shah of Gujarat who hoped to use him against their common Mughal enemy. Characteristically, Sher Khan did not share these resources with the Luhanis but used them to increase his own power, recruit men into his service, train them, and thus, again, to attack the tribal basis of the realm. 'Laying aside every bond of friendship and respect for the honour of the Afghans (nämūs-i-afghānān), they all bowed down without hesitation and delay before his irresistible farman' (Sarwani 1964: I, p. 231). Fixed salaries, equal opportunity employment, and discipline replaced clan loyalty. As a result, by the end of the 1530s, says Abbas Khan Sarwani, 'Sher Khan was known for his qualities of generosity and benevolence; throughout the day he was occupied in scattering gold like the sun and shedding pearls like clouds and this was the reason that the Afghans gathered around him and the kingdom of Hind fell into his hands' (Sarwani 1964: I, pp. 224-225; II, p. 178). Most Afghans, including his own Sur tribesmen, continued to live in mobile camps, and many were still commuting on an annual basis, with their wives and children. When Sher Khan became convinced that all Afghans had united with him and were eager to fight the Mughals, he came out of the hills of Rohtas and marched to engage Humayun, routing the latter at Chausa in 1539, then at Kanauj in 1540. This was the time Sher Khan ascended to the throne as Sher Shah. Like Bahlul and Sikandar Lodi, he did so after overcoming considerable hesitation. He almost had to be dragged to the throne, if we can believe Abbas Khan Sarwani (1964). In the end, Sher Khan was ceremoniously enthroned amidst tribal dancing festivities that went on for seven days. The khutba or Friday prayer was read in his name, coins were issued, and he was given the title of Shah Alam.

The flight of the Mughal emperor Humayun left Sher Shah the unchallenged ruler at Agra between 1540 and his death in 1545. During these years his sustained attempt at imperial centralization and military reform went well beyond the measures taken by his Lodi predecessors. Extending his policies of the preceding decade, Sher Shah emphasized hierarchical subordination to and direct employment by the center instead of horizontal linkages with tribal leaders and warlords. A whole new political economy was devised and implemented to recruit, pay, train and discipline a professional army. Making the most methodical and productive use of his time, Sher Shah supervised all campaigns and affairs of state, no matter how great or small, in person. Reliance on courtiers was avoided as much as possible, while none was allowed to do anything without his consent. Sher Shah everywhere set spies on his nobles. The ranking system of mansabs the Lodis had introduced was again implemented among Sher Shah's nobility, but much more systematically, and in combination with more closely audited revenue assignments or jagirs. After 1540, instead of hoarded wealth and booty the regularly assessed land revenue became the major source of income of the imperial state, while rules regulating the payment of soldiers' salaries and the branding of horses (dagh) were implemented with great rigour. 'In every country that came into his possession,' writes Abbas Khan Sharwani', he [Sher Shah] exerted himself in its development and agricultural improvement... he personally looked into all its affairs and paid its soldiers regularly without oppressing the peasants...The Afghan army swelled to unprecedented proportions' (Sarwani 1964: I, pp. 79, 211-2; II, pp. 58, 165). He built an alleged 1700 caravanserais and what later came to be called the Grand Trunk Road and introduced an improved system of news transmission. Showing none of the customary Afghan contempt for fortification, Sher Shah built especially massive stone fortresses, in Delhi and elsewhere, and even introduced a novel system of earthen entrenchments to protect his mobile camp sites. He protected peasants and agriculture against moving armies and cast artillery. Like his Lodi predecessors but even more so, Sher Shah associated himself with Turks, Farmulis, and Rajputs in order to expand the non-Afghan base of his empire. Making use of more or less powerful non-Afghan middlemen, he recruited substantial zamindari contingents and peasant soldiers in his military. These too were accommodated within the new Afghan imperial system under his own aggressive leadership. The second Afghan empire, thus, owed little to ethnic and tribal loyalties and segmentary politics but founded itself on direct recruitment and individual enterprise.

Islam Shah, succeeding to the imperial throne in 1545 , resembled his father in his desire for dominion and conquest, and began his reign by bringing the entire country under his personal control by perpetuating many of his civil and military regulations, including the branding system and the mansabs ${ }^{1}$. Like his father, he assembled an immense army, consisting of cavalry, elephant battalions, and possibly as many as sixty large guns. However, having garrisoned 
the entire country between Kabul and Bengal with his own troops, he soon set about destroying his father's nobles. For two years he forced his Afghan soldiers to do manual work, carrying stone and lime, building yet more forts. Opposition against Islam Shah intensified as a result of these ill-calculated and perverse measures, while tribal factionalism and the intemperate Afghan blood feuds and revenge killings re-surfaced with a vengeance. An epidemic of bubonic plague ravaged the whole of Hindustan in 1550. Two years later Islam Shah followed his father to the family grave in Sahsaram.

The fall of the second Afghan empire was now at hand, immediately after Islam Shah's death, and the Sur domains were partitioned among several sons and relatives of Sher Shah. By 1554 three different khutbas were read in Hindustan and three kings, openly declaring war on each other, issued their own sikka coinage. This was the time of the 'kings of the clans.' In the ensuing free-for-all, some two hundred aspiring Afghan amirs obtained royal tents, standards and kettle drums, while any Afghan who brought with him ten or fifteen horsemen was given a makeshift flagstaff with a bit of red rag wrapped around it, with some other dignities and a jagir. Among the old Afghan nobility of Lodi times extreme demoralization set in, in 1555 aggravated by the outbreak of severe famine conditions (caused by drought) in eastern Hindustan. When Humayun 'received intelligence of the dissensions of the [Afghan] nobles, and the partition of the territories of Hind, he felt persuaded that the discordance of the Afghans would enable him to take possession of the country' (Hidayat Hosain 1939:301). And thus, as one Mughal historian, Badauni, put it,'the kingdom fell away from the race of the Afghans and returned to its original holders' (Badauni 1990: I, 436). Ironically, Sher Shah left an important legacy of state building efforts and administrative measures, as well as a physical infrastructure of countless caravanserais and the early Grand Trunk Road -now an archaeological site of great interest- across northern India, to his longterm Mughal rivals, not his Afghan fellow countrymen.

\section{References Cited}

Arlinghaus, J.T. 1983. The Transformation of Afghan Tribal Society: Tribal Expansion, Mughal Imperialism and the Roshaniyya Insurrection, 1450-1600. Unpublished PhD Dissertation, Duke University, Durham, North Carolina.

Bâburnâma 1993. Chaghatay Turkish Text with Persian Edition and English Translation by W. M. Thackston, JR. 3 Volumes. Sources of Oriental Languages and Literatures XVIII. Harvard University, Cambridge, Massachusetts.

Badauni, Abd al-Qadir 1990. Muntakhab at-Tawarikh. 3 Volumes, ranking translation, New Delhi.

Digby, S. 1965. Dreams and reminiscences of Dattu Sarwani, a sixteenth-century Indo-Afghan soldier. The Indian Economic and Social History Review 2:52-80, 178-194.

Elphinstone, M. 1992 [1815]. An Account of the Kingdom of Caubul. 2 Volumes. Karachi.
Hidayat Hosain, M. (ed.) 1939. Tarikh-i-Shahi of Ahmad Yadgar, Calcutta.

Masson, Ch. 1997-2001 [1842]. Narrative of Various Journeys in Balochistan, Afghanistan and the Panjab, 1826 to 1838. 4 Volumes. New Delhi.

Raverty, H.G. 1888. Notes on Afghanistan and Parts of Baluchistan, Geographical, Ethnological, and Historical. London.

Robinson, J.A. 1978 [1934]. Notes on Nomad Tribes of Eastern Afghanistan. Lahore.

Sarwani, A.K. 1964 [1580]. Tarikh-i-Sher Shahi. Dhaka.

Wink, A. 1990-2004. Al-Hind: The Making of the Indo-Islamic World, 3 Volumes. Brill, Leiden and Boston.

Wink, A. 2018. Al-Hind: The Making of the Indo-Islamic World. 4 Volume. Brill, Leiden and Boston.

\section{Note}

${ }^{1}$ Rank system for civil and military officers introduced in the Akbar regime. 